\title{
Land Hunger in Omo Forest Reserve, Area J4, Ogun State Prospects: Of Creating Harmony among Land Users
}

\author{
*1'SALAKO, BA; ${ }^{1}$ ADESOPE, AAA; ${ }^{2}$ AGBEJA, BO \\ ${ }^{*}$ Forestry Research Institute of Nigeria, P. M. B. 5054, Jericho, Ibadan \\ ${ }^{2}$ Faculty of Renewable Natural Resources, University of Ibadan, Nigeria \\ *Corresponding Author Email: adesolab21@gmail.com; Tel: 09055237553
}

\begin{abstract}
The study verified the extent of land hunger in Omo Forest Reserve, area J4, Ogun State, with a view to creating harmony among land users. Five villages/communities (Osoko, Aberu, Fowowa, Bashiru and Oloji) in Omo Forest Reserve, area J4, Ijebu East, Ogun State were selected for the study due to the level of their involvement in farming activities. Data was obtained using two set of structured questionnaire and analyzed using descriptive statistics and binary logistic regression at $\alpha=0.05$. A high level of land hunger was proven and its main causes (population increase and area of forest reservation) were identified. Good governance in the affairs of the reserve, followed by the empowerment of the people to have a say in the management of the forest reserve and a holistic land use policy, with odd ratios of $3.85,2.73$ and 2.37 , respectively would highly influence the reduction of conflict between farmers and foresters in Omo Forest Reserve (J4).
\end{abstract}

\section{DOI: $\underline{\text { https://dx.doi.org/10.4314/jasem.v24i5.5 }}$}

Copyright: Copyright $(\subset) 2020$ Salako et al. This is an open access article distributed under the Creative Commons Attribution License (CCL), which permits unrestricted use, distribution, and reproduction in any medium, provided the original work is properly cited.

Dates: Received: 11 March 2020; Revised: 19 April 2020; Accepted: 21 April 2020

Keywords: conflict, harmonisation, land hunger, forest reservation and land use.

Peace and harmony among the stakeholders in an organisation are major factors of development, since economic activities that bring about development can only thrive in a peaceful atmosphere. However, achieving peace seems to be a huge task, especially in Africa, where forest reserves have become spots of major conflicts. FAO (2012) observed that conflict is natural in forest management because it has different objectives and therefore, many stakeholders (local forest users, different government agencies (in and outside the forest administration), civil society, and the private sector) who often have competing interests. According to Agbeja and Otesile (2011), land hunger has been one of the major problems causing conflicts in Omo Forest Reserve, Area J4, Ogun State. As the population of the people living within the communities increases, the need for land to meet social and economic needs (like food, shelter, infrastructure and income) also increases. The scarcity of land outside forest reserves to accommodate the increasing demand makes farmers without secure rights of access to land see the reserves as a favourable alternatives as a result of the ease of access. Over the years, the clearing of forest lands for agriculture, which contributes significantly to greenhouse gas emission (Agbeja, 2010), has led to serious conflicts between farmers and foresters. A type of multiple land use (taungya) was introduced to solve this problem and it was successful for a while. But over time, farmers started planting tree crops on the land, thereby laying claim/right of ownership on the land constituting the forest reserve. A clear knowledge of the extent of land hunger in the state forest reserves according to Agbeja and Otesile (2011) is presently lacking, hence, the need to address the following queries. What is the extent of land hunger among farmers in Omo Forest Reserve Area J4, Ogun State? What are the causes of land hunger in Omo Forest Reserve Area J4, Ogun State? What are the factors that can help in the reduction of conflicts among land users, thereby harmonizing the farmers and foresters within the reserve? In other to provide answers to the preceding questions, the objective of this paper is to identify the cause and extent of land hunger in Area J4 of Omo Forest Reserved and determine the institutional factors that will reduce conflict amongst land users in Ogun State, Nigeria.

\section{MATERIALS AND METHOD}

Study Area: Omo Forest Reserve is located between latitudes $6^{0} 35^{\prime}$ to $7^{0} 05^{\prime} \mathrm{N}$ and $4^{0} 19^{\prime}$ to $4^{0} 40^{\prime} \mathrm{E}$ in the eastern part of Ijebu area of Ogun State, Nigeria. It is about $135 \mathrm{~km}$ north-east of Lagos, about $120 \mathrm{~km}$ east of Abeokuta and about $80 \mathrm{~km}$ east of Ijebu Ode. The terrain of the reserve is undulating and the maximum elevation of $150 \mathrm{~m}$ above sea level is towards the west 
while the lowest parts of the reserve are in the south where the River Omo joins River Oni (the reserve's eastern boundary) before flowing into the Lekki peninsular on the Atlantic coast (Isichiei, 1995). It covers an area of about 130,500 hectares or 322,247.53 acres (Ojo, 2004).

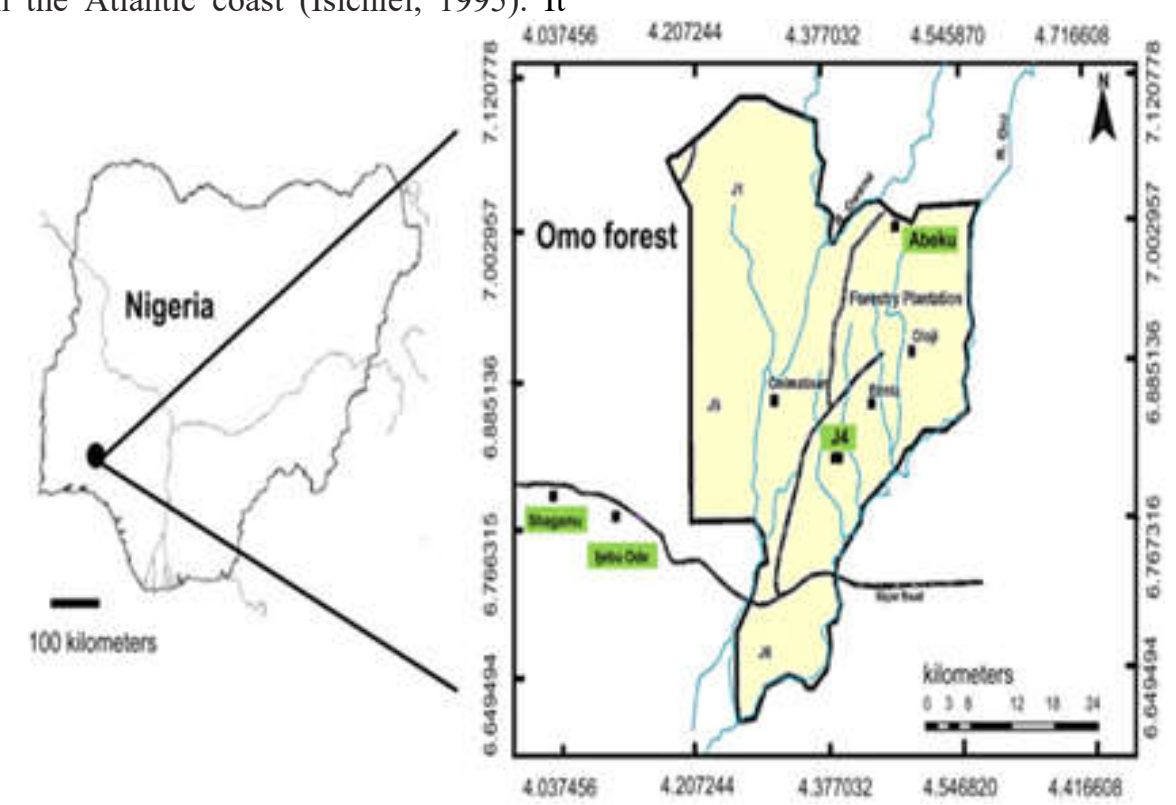

Fig 1: Map of Omo Forest Reserve (Area J4), Ogun State, showing some of the villages constituting the study area. Source: Attah et al., (2016)

Data Collection and Analysis: Primary data was obtained through two sets of structured questionnaire and an oral interview. Five villages (Osoko, Oluoji, Fowowa (J4), Aberu and Bashiru) were purposefully selected due to their level of involvement in farming activities. The sampling intensity used was in conformity with the recommendation of Diaw et al., 2002 that a sampling intensity of $10 \%$ can be used to represent a population that is not more than 100 . Since hypothetical population of each of the communities was over 200 (adults; male and female), 20 respondents from each village and 20 forestry officials were randomly selected and interviewed. The data collected were subjected to descriptive analysis (such as tabular presentation, which includes frequency analysis and percentages) and the binary logistic model (STATISTICA Version 7 software was used)

The binary logistic models are very useful in situations where the dependent or response variable is binary in nature. This implies that they can have only two possible values. Distinct information provided by logit is the odds ratio and it is defined as the ratio of the odds of an event occurring in the group to the ratio of it occurring in another group (Altman, 2000). The logit of a response $\mathrm{p}$ between 0 and 1 is given as:

$$
\operatorname{logit}(p)=\log \left(\frac{p}{1}-p\right)=\log (p)-\log (1-p)
$$

The simplest form of the logit model is expressed as:

$$
\operatorname{logit}(p i)=a+b x i
$$

Where, $\mathrm{X}_{\mathrm{i}}=$ vector of prediction or independent variables, $\mathrm{a}$ and $\mathrm{b}=$ regression parameters

In binary models, the two possible results are assigned values of 1 or 0 . Therefore, in this study, an affirmative response to a factor that would reduce conflict among land users was assigned a value of 1 but a negative response to a factor that would reduce conflict between land users is assigned a value of 0 . Reduction of conflict between land users $=\mathrm{f}\left(\mathrm{x}_{1}, \mathrm{x}_{2}\right.$, $\left.\mathrm{x}_{3}, \mathrm{x}_{4}, \mathrm{x}_{5}, \mathrm{x}_{6}, \mathrm{x}_{7}\right)$

$$
\operatorname{Logit}(R C B L U)=a+b \times 1+b \times 2+b \times 3+b x 4+b \times 5
$$

Where: RCBLU $=$ Reduction of conflict between land users, $\mathrm{x}_{1}=$ Good governance in the affairs of land use, $\mathrm{x}_{2}=$ Holistic land use policy, $\mathrm{x}_{3}=$ Empowerment of the people, $\mathrm{x}_{4}=$ provision of improved taungya, $\mathrm{x}_{5}=$ Re-enforcement of laws governing the use of the reserve. The parameter for this study was analysed using the Quasi-Newton method under the logistic regression (logit) option of the STATISTICA Version 7 software. Chi-square tests of independence were also used to rate the interaction of the variables with others. 
For the test to be assumed significant, the P-level has to be less than 0.05 .

\section{RESULTS AND DISCUSSION}

Socioeconomic Characteristics of the Land Users (Farmers): Table 1 show that, $31.4 \%$ of the respondents were between 41 and 50 years old while $27.1 \%$ fell within 51-60years age bracket. The distribution of ages show that youths (21-30) were not really involved in farming as only one respondent $(1.1 \%)$ fell within that age range while the rest of the farmers in the reserve were between the ages of 41 and 60. Most of the respondents $(59 \%)$ had secondary education while the remaining $40 \%$ had primary education. The result also shows that $82 \%$ of the respondents were primarily farmers who planted either cash or food crops for sale. So apart from forestry, farming can be said to be the main stay of the economy in $\mathrm{J} 4$.

Table 1: Demographic Characteristics of the Respondents (Farmers)

\begin{tabular}{|c|c|c|}
\hline Gender & Frequency & $\%$ \\
\hline Male & 69 & 69 \\
\hline Female & 31 & 31 \\
\hline Total & 100 & 100 \\
\hline Age & Frequency & $\%$ \\
\hline $21-30$ & 1 & 1.1 \\
\hline $31-40$ & 16 & 17.3 \\
\hline $41-50$ & 28 & 31.4 \\
\hline $51-60$ & 25 & 27.1 \\
\hline $61-70$ & 9 & 9.8 \\
\hline $71-80$ & 8 & 8.8 \\
\hline $81-90$ & 4 & 4.3 \\
\hline Total & 100 & 100 \\
\hline Level of education & Frequency & $\%$ \\
\hline Primary & 41 & 41 \\
\hline Secondary & 59 & 59 \\
\hline Tertiary & 0 & 0 \\
\hline Total & 100 & 100 \\
\hline Number of years farmed & Frequency & $\%$ \\
\hline $0-9$ & 29 & 29 \\
\hline $10-19$ & 30 & 30 \\
\hline $20-29$ & 21 & 21 \\
\hline $30-39$ & 16 & 16 \\
\hline $40-49$ & 1 & 1 \\
\hline $50-59$ & 3 & 3 \\
\hline Total & 100 & 100 \\
\hline Primary occupation & Frequency & $\%$ \\
\hline Farming & 82 & 82 \\
\hline Others & 5 & 5 \\
\hline Farming and others & 13 & 13 \\
\hline
\end{tabular}

Socioeconomics Characteristic of Foresters: Table 2 shows that $90 \%$ of the foresters are males and the majority (70\%) were between the ages of 21 and 40; $90 \%$ had tertiary education and most of the respondents are not indigenes of Ogun State
Table 2: Foresters Demographic Information

\begin{tabular}{lll}
\hline Gender & Frequency & $\%$ \\
\hline Female & 2 & 10 \\
Male & 18 & 90 \\
Total & 20 & 100 \\
\hline Age & Frequency & $\%$ \\
\hline $21-40$ & 14 & 70 \\
$41-60$ & 6 & 30 \\
Total & 20 & 100 \\
\hline Level of education & Frequency & $\%$ \\
\hline Secondary & 2 & 10 \\
Tertiary & 18 & 90 \\
Total & 20 & 100 \\
\hline Years of work & Frequency & $\%$ \\
\hline $1-20$ & 14 & 70 \\
$21-40$ & 4 & 20 \\
Missing & 2 & 10 \\
Total & 20 & 100 \\
\hline Nativity of foresters & Frequency & $\%$ \\
\hline Yes & 5 & 25 \\
No & 15 & 75 \\
Total & 20 & 100 \\
\hline \multicolumn{3}{l}{ Source: Field Study, 2018 }
\end{tabular}

Extent of Land hunger and its possible cause: Table 3 shows that, approximately, $80 \%$ of the respondents farmed on a land area that is less than 1(one) acre. The respondents with a land area that was above 30acres were chiefs or village heads and their property was inherited from their parents. The result also shows that the level of land hunger in Omo Forest Reserve, area $\mathrm{J} 4$, is very high as an area of land that is less than lacre is too small for commercial farming, which seems to be the culture in this area. The main cause of land hunger, according to $53.4 \%$ of the respondents, was the area of forest reservation (area covered by the forest reserve). Those who attributed it to population increase constituted approximately $27 \%$

Table 3: Land hunger and its causes in Omo Forest Reserve

\begin{tabular}{lll}
\hline Area of land (acres) & Frequency & $\%$ \\
\hline Less than 1 & 79 & 79 \\
$1-5$ & 10 & 10 \\
$6-10$ & 4 & 4 \\
$11-20$ & 4 & 4 \\
Above 20 & 3 & 3 \\
\hline Types of crops grown & Frequency & $\%$ \\
\hline Cash crops & 38 & 38 \\
Food crops & 39 & 39 \\
Both & 22 & 22 \\
Food crops and others & 1 & 1 \\
Total & 100 & 100 \\
\hline Availability of land in the area & frequency & $\%$ \\
\hline Adequate & 24 & 24 \\
Inadequate & 76 & 76 \\
Total & 100 & 100 \\
\hline Possible causes of land hunger & Frequency & $\%$ \\
\hline Population increase & 8 & 11 \\
Area of forest reserve & 39 & 53.4 \\
Population increase and farm expansion & 1 & 1.4 \\
Population increase and area of reserve & 22 & 30.1 \\
Population increase, area of reserve and & 3 & 41 \\
farm expansion & & \\
\hline \multicolumn{2}{c}{ Source: Field Study, 2018} & \\
\hline
\end{tabular}


Institutional Factors That Can Help to Reduce Conflicts among Land Users in Omo Forest Reserve: Binary logistic regression analysis was used to investigate measures that will reduce conflict and bring about harmony between foresters and farmers in Omo Forest Reserve. The institutional measures investigated were Good governance in respect of land use in the reserve (GG), Holistic land use policy (LUP), Empowerment of the people to have a say in the management of land in the forest reserve (Emp),

$$
\begin{gathered}
\operatorname{logit}(\mathrm{pi})=a+\text { bxi } \\
R C B L U=-1.92+1.35 \mathrm{GG}+0.86 \mathrm{LUP}+1.01 \mathrm{Emp}+0.68 \operatorname{Impt}-0.06 \text { Laws } \\
\text { Final loss }=57.87 ; \text { Chi square }(\mathrm{df}, 5)=32.62 ; \mathrm{p}=0.00001^{*}
\end{gathered}
$$

provision of improved taungya (Impt) and Reenforcement of laws governing the use of the reserve (Laws). The dependent variable was Reduction of Conflict between Land Users (RCBLU) and the independent variables were the investigated institutional factors listed above. The response of the foresters (20) and those of the farmers (93) were pooled. The model obtained for the study is presented as follows:

Odd ratios unit change: constant (0.15); GG (3.85), LUP (2.37); Emp (2.73) ; Impt (1.98) ; Laws (0.94),

Where: RCBLU $=$ Reduction of Conflict between Land Users in Omo Forest Reserve (yes $=1$; no $=0$ ), $\mathrm{GG}=$ Good Governance in the Affairs of Land Use in the Forest Reserve (yes $=1$; no $=0$ ), LUP $=$ Holistic Land Use Policy (yes =1; no =0), Emp: Empowerment of the people to have a say in the management of land in the forest reserve (yes $=1$; no $=0$ ), Impt $=$ Provision of Improved Taungya System (yes $=1$; no $=0$ ), Law $=$ Re-enforcement of laws governing the use of the forest reserve (yes $=1$; no $=0$ )

The equation presented above for reduction of conflict between land users in Omo Forest Reserve, Area J4, Ogun State gave an overall significant fit going by the Chi-square value $(0.00001)$ that is significant at $\mathrm{p}<0.05$.This implies that the regression parameters in the model were statistically significant.

Table 4 shows that the RCBLU would be most positively influenced by GG, followed by Emp and lastly by LUP as they had odds ratios that are greater than 2: $3.85,2.73$ and 2.37 respectively. The implication of this result is that if there was good administration in the affairs of land use in the reserve, if there was less bureaucracy and more of just and fair rules and judgement, if perpetrators of offences are duly punished without putting their level or rank as foresters or their influence in the villages into consideration, there would be harmony among the land users. The second most influential factor was the empowerment of the people to have a say in the management of the land in the forest reserve. Research has shown that people tend to obey more the laws they help in formulating, Adebayo (2019) noted that little was achieved in the reservation of $25 \%$ of the country's land area due to stiff resistance by local community dwellers who rightly established their claim to the land. So if the people are empowered through various forest extension and empowerment approaches to see the forest more as a benefit/blessing to all and their representatives are allowed to participate actively in taking major decisions concerning the managements goals, objectives and resource assessment of the forest reserve, the level of conflict among foresters and farmers will be reduced to the barest minimum. The least influential factor was holistic land use policy. Agbeja (2010) opined that a nation without a comprehensive land use policy will surely face a lot of land-use problems. Also, a nation that inadequately implements its land-use policy will face similar problems. According to Johnson (2010), a holistic land use policy that will cater for the needs of both the agricultural and forestry sector will bring about harmony between the two sectors. A holistic land use policy is the solution to most land-use conflict issues.

Table 4: Binary logistic nature of Institutional Factors That Can Help to Reduce Conflicts among Land Users (foresters and farmers) in Omo Forest Reserve

\begin{tabular}{lll}
\hline Dependent Variable & & \\
\hline RCBLU & & \\
\hline Constant & -1.95 & 1.15 \\
\hline & Coefficient & Odds ratio \\
\hline Independent variables & 1.35 & $* 3.85$ \\
\hline Presence of good governance & 0.86 & $* 2.37$ \\
Holistic land use policy & $* 2.73$ \\
Empowerment of the people & 1.01 & \\
$\begin{array}{l}\text { Provision of improved } \\
\text { taungya system }\end{array}$ & 0.68 & 1.98 \\
Re-enforcement of forest laws & -0.06 & 0.94 \\
\hline \multicolumn{2}{c}{ Source: Field study.2018 } \\
\hline
\end{tabular}

Conclusion: Land hunger is evident in Omo Forest Reserve and the resulting conflict is beyond boundaries as all stakeholders are affected. Therefore, government should manage the affairs of the reserve with equity and transparency, by enunciating a holistic land use policy that will define the place of agriculture within the reserve and put restrictions on all illegal practices. Alternative means of livelihood for the inhabitants of the forest communities should also be encouraged and forestry extension workers should be 
sent to the reserve to increase their knowledge of the reserve.

\section{REFERENCES}

Adedayo, AG (2019). Evaluation of Occurrence and Resolution of Conflicts in and around Forest Reserves in Ondo State. Inter. J. Res. Stud. Agric. Sci. 5(3): 8-18

Agbeja BO (2010). Binary model for assessment of conflict between forestry and agricultural land use in southwest Nigeria. J. Environ. Extent. 9(5): 3341

Agbeja, BO; Otesile, A. A (2011). Conflict and Forest Land-Use: A Case Study of Forest Reserves in Ogun State, Nigeria. Forests and Forest Products J. 4: 61-74

Attah, FA; Hellinger, R; Sonibare, MA; Moody, JO; Arrowsmith, S; Wray, S; Gruber, CW. (2016). Ethobotanical survey of Violaceae used in SouthWestern Nigerian Ethnomedicine and Detection of Cyclotides. J. Ethnopharmacology. 179: 83-91

Azeez, IO; Amusa, TO (2014). Participatory Forestry Practices and Renewable Natural Resources Management. Proceedings of the $37^{\text {th }}$ Annual conference of the Forestry Association of Nigeria, p.397
Diaw, K; Blay, D; Adu-anning, C. (2002). Socioeconomic survey of forest fringe communities: Krososua Hills Forest Reserve. A report submitted to the Forestry commission of Ghana. 86pp

Food and Agriculture Organization of the United Nations (2012) Conflict Management in Forestry

Isichie, AO (1995). Omo Biosphere Reserve; Current status, Utilization of biological resources and Sustainable management: South-south cooperation on environmentally sound socioeconomic development in the humid. Working paper II, UNESCO, Paris 48pp

Martin, BJ; Douglas, GA (2000). The odds ratio; The British Med. J. 320:1468

Johnson, BM (2010). Assessment of conflict between Forestry and Agricultural land use in Ijaiye Forest Reserve, Oyo State: Prospect for Reconciliation"31-68pp (unpublished)

Ojo LO (2004). The Fate of a Tropical Rainforest in Nigeria: Abeku Sector of Omo Forest Reserve. Global Nest: The Inter. J. 6(2): 116-130

World Bank development report (2014) 